\title{
Application of Contextual Teaching and Learning Models Based on Creative Thinking in Elementary Schools
}

\author{
Miratu Chaeroh ${ }^{1,}$ St.Y. Slamet ${ }^{2,}$ Sandra Bayu Kurniawan ${ }^{3}$ \\ 1,2,3 Faculty of Teacher Training and Education Universitas Sebelas Maret \\ Corresponding email: miratuchaeroh95@gmail.com
}

\begin{abstract}
This study aims to describe the analysis of the contextual learning model (CTL) in social science subjects based on creative thinking in class IV SDIT An Nisa 'Kedawung Sragen. The problem in research is related to the implementation of the learning model and learning system at SDIT An Nisa 'Kedawung in implementing the contextual teaching and learning (CTL) learning model. Facts in the field of students tend to be passive, do not answer in learning so that the impact on the learning process is low. The method used in this research is a qualitative method with a case study approach. The population consisted of 44 students consisting of 21 male students and 23 female students. The results of this study are expected through the contextual learning model (CTL) based on the creative thinking of students who can think creatively and enthusiastically in participating in the learning process so that it has an impact on the learning process that is effective and interesting. Based on these findings, this study studied contextual learning and learning (CTL) based on creative thinking to be implemented in elementary schools.
\end{abstract}

Keywords: Contextual Teaching and Learning (CTL), Creative Thinking

\section{INTRODUCTION}

\subsection{Introduce the Problem}

Education is a very decisive process for individual development and community development. Education has an influence on changes in a person according to his expertise. The educational process can be obtained anywhere, both formal and informal education. Formal education can be obtained through school education starting at the elementary, junior high, and high school levels, while informal education can be obtained from the surrounding environment, family, and community. Such is the importance of education for the lives of Indonesian citizens as stated in Article 31 paragraph 1 of the 1945 Constitution which reads "every citizen has the right to education." The implementation of education in Indonesia certainly has obstacles in every implementation of learning, especially at the formal education level. In the implementation of learning in elementary schools, every teacher always faces different and challenging situations that have a big influence on the learning process. Efforts to improve the quality of the learning process in the classroom must be carried out because the essence of improving the quality of education is increasing the quality of the implementation of the learning process in the classroom. The learning process will be interesting if it is balanced with the use of a learning model. One example of applying the learning model in elementary schools is the contextual teaching and learning (CTL), learning model.

Contextual teaching and learning (CTL) learning model is a learning model that connects learning material with real-world situations that occur around the environment so that students can more easily understand the material being studied and can be applied in everyday life. Contextual Teaching and Learning (CTL) aims to increase students' motivation to take what they have learned and apply it, making it meaningful in the context of actions and interactions in their daily situations [11]. Contextual teaching and learning (CTL) is based on cognitive research where processes such as critical thinking, inquiry learning, and problem-solving must be placed in relevant physical, intellectual, and social contexts [15]. CTL is a constructivist learning approach that focuses on knowledge that is highly contextual and 
relevant to students [10]. Learning with CTL makes students' answers more varied than conventional learning [19]. The CTL learning strategy is an educational process that aims to help students see meaning in the academic material studied by connecting academic subjects with the content of everyday life, namely in the context of personal, social, and cultural life [14]. The application of CTL can help students to understand concepts and be skilled at solving problems [25]. This difficulty in implementing CTL is seen when trying to capture or predict what students are learning [20]. In general, teachers in delivering material have used the contextual teaching and learning (CTL) learning model but have not yet aroused the enthusiasm of students to think creatively. This has an impact on the attitudes of students when learning, among others, students feel bored, not enthusiastic, and less creative in following the learning process which has an impact on low learning outcomes.

Creativity is an important aspect of learning [29]. Creative thinking shares many of the same characteristics as traditional complex tasks [27]. Creativity is the ability to be creative, to produce new things. The human brain can reach new conclusions and ideas and to solve problems in original ways [12]. In the past, creativity was believed to be a skill that was blessed by divine beings only to those with special privileges. Likewise, creativity is considered a new form of thinking, where problems are reassessed, knowledge gaps are identified, leading to the emergence of new ideas, then the resulting ideas are analyzed, and finally, the logical risks in idea making are taken after weighing the consequences [18]. The relevance of the problem of forming creative thinking among students in the field of pedagogical training is explained by the current contradiction between society's need for creative teachers, creative thinking and the insecurity of professional-pedagogical training systems the conditions necessary for organizing the process of shaping creative thinking among future teachers [8].

Creativity is defined as the sensitivity that arises to problems [9]. Creativity is also related to innovation, namely, students can think creatively, work creatively, and create innovations [24]. Creative thinking is related to practice as a process of directing students to the formation of creative thinking skills in aspects of originality. This process refers to Vygotsky's constructivist theory in which learning is most effective when students can relate what they are learning to the environment and by creating meanings from different experiences [37]. Creative thinking has helped develop the learning process and make it positive [28]. Creative thinking is project-oriented learning by providing a broad field for the formation of creative thinking and creativity (both by students and teachers) [34]. Creative teachers are individuals who have self-confidence, are open to communication and innovation, and guide students, role models for them with every behavior and encourage them [5]. In answering teacher questions, students are encouraged to think by expressing ideas that are flexible, versatile, and original [36]. Due to its importance as an educational product, many studies have investigated the effectiveness of several methods and strategies intended to enhance creative thinking among students at various stages of development [1]. One example of creativity, namely expressive creativity, is a type of spontaneous creativity that is often seen in children and is exemplified in drawing and playing [6]. Creativity can be developed with training, and various studies assessing the effects of programs on stimulating creativity to confirm this belief [2]. Statistically, there is a significant relationship between creative thinking and student achievement and its implications for education as a whole [3]. Related to this problem, this study analyzes the application of contextual teaching and learning (CTL) based on creative thinking in elementary schools.

\subsection{Similar Research}

Research on the implementation of contextual teaching and learning (CTL) learning model based on creative thinking has also been carried out by previous researchers. There are several examples of research including research written by Abu Nawas with the title "Contextual Teaching And Learning (CTL) Approach Through React Strategies On Improving The Students' Critical Thinking In Writing." The results of the study show that the statistically significant difference at $(\alpha=$ 0.05 ) between the achievements of the experimental group and the control group on the post-test supports the experimental group. The difference implies that the implementation of the CTL approach through the REACH strategy is effective for improving students' writing skills. The mean and standard deviation values for the experimental group at post-test were $(\mathrm{M}=4.9, \mathrm{SD}$ $=0.43)$ while those in the control group were $(\mathrm{M}=3.49$, $\mathrm{SD}=0.25)$ [23].

Another study on the contextual teaching and learning (CTL) learning model was also written by Shawn, Linda K. who stated that the conditions that drive the implementation of the CTL strategy are collaborative interactions with students, high levels of activity in lessons, connection to real-world contexts, and integration. science content with other content and skill areas. Furthermore, the CTL strategy is best applied when teachers use it in conjunction with sound classroom management techniques [13].

Research on the contextual teaching and learning (CTL) learning model was also expressed by Toheri, Widodo, Arif with the title Where Exactly for Enhance Critical and Creative Thinking: The Use of Problem Posing or Contextual Learning which shows an increase in critical and creative thinking skills, including in Medium category for types that use contextual learning and problem-solving. The results of other research show that contextual learning is more effective in improving 
critical thinking skills when compared to learning problems and expository learning [35]. Here it explains that contextual learning is proven to be effective in increasing the level of critical thinking of students during the implementation of learning.

Research conducted by Batlolona, et al with the research title Creative Thinking Skills Students in Physics on Solid Material Elasticity concluded that the learning process at the level of students' creative thinking skills was still different. In the PBL class, the highest achievement of CTS was on the topic of springs and parallel arrangement, while in conventional learning on the topic of stress, strain, and Young's modulus. The lowest CTS achievement for both the PBL class and the control class was the same on the topic of Hooke's law. Thus, the PBL learning model can improve students' CTS posttest scores on elasticity material. Besides, PBL can be recommended in developing or training students' creative thinking [7]. In this study, the PBL learning model can be used to observe students during the implementation of learning which is proven to increase the level of student creativity.

The research was written by Syahrin, Dawud, Suwignyo, \& Priyatni which states that in general the findings of research on creative thinking patterns in students' scientific work show that creative thinking patterns lie in the form of ideas used [33]. The research was also conducted by Puspitasari, In'an, \& Syaifuddin with the title Analysis of Students' Creative Thinking in Solving Arithmetic Problems. The results showed that mathematics subjects that were included in the high ability category did not show problems related to the aspects of fluency, flexibility, and originality, except in the aspects of elaboration. Students with moderate mathematical abilities still have difficulty understanding mathematical problems, this can be seen from the steps in solving them which are less structured, detailed, and systematic, especially for the first problem [26]. Here to overcome these difficulties, the student's creative thinking process is applied to solve problems in arithmetic material.

Another study entitled Analysis of senior high school students' creative thinking skills profile in Klaten regency. This study concludes that the initial profile of students' creative thinking skills in biology learning is low. The results showed that the creative thinking skills of high school students should receive serious attention considering the low percentage on each indicator [30]. From the information above, it can be used as a reference regarding the implementation of contextual teachinglearning based on creative thinking in elementary schools.

\subsection{Research Objectives}

The general objective of this study is to describe the overall implementation of learning by applying the contextual teaching and learning (CTL) learning model based on creative thinking in learning in elementary schools. While the specific objectives are 1) knowing the implementation of the contextual teaching and learning (CTL) learning model based on creative thinking, 2) the obstacles to the creative thinking-based Contextual Teaching and Learning (CTL) learning model and 3) Solution to problems in the implementation of learning by applying the contextual teaching-learning model. and Learning (CTL) based on creative thinking.

\section{METHODS}

This research method, the type of research that can be used is descriptive qualitative research. The method used in this research is a qualitative approach. Qualitative research methods are often called naturalistic research methods because the research is conducted in natural conditions (natural setting); it is also called the ethnographic method because initially this method was more widely used for research in the field of cultural anthropology; referred to as a qualitative method because the data collection and analysis is more of a qualitative nature [32]. In this study, the researcher wanted to reveal the form of research by analyzing the implementation of learning with the contextual teaching and learning (CTL) learning model based on creative thinking in elementary schools.

The research strategy used is a case study. Case studies are descriptions and comprehensive explanations of various aspects of an individual, a group, an organization (community), a program, or a social situation [22]. Another case study definition is an empirical inquiry that investigates phenomena in a reallife context, where the boundaries between the phenomenon and the context are not visible and where multiple sources of evidence are exploited [16]. This research is called embedded case study research because the research is carried out in one school with the specificities and problems in the research that have been determined in advance by the researcher. Research on the implementation of the contextual teaching and learning (CTL) learning model based on creative thinking was carried out in group IV SDIT An Nisa ', Kedawung subdistrict, Sragen district. The reason for choosing this research location was because of the low ability of students in implementing contextual teaching and learning (CTL) learning models based on creative thinking in this school and similar research had not been carried out.

The research subject according to Arikonto defines research subject as an object, thing, or person where the data for the research variable is attached, and which is in trouble [4]. The subjects of this study were fourth-grade students of An Nisa 'Integrated Islamic Elementary School, Kedawung District, Sragen Regency. The reasons for choosing class IV, namely wanting to know 
the implementation, obstacles, and solutions of the contextual teaching and learning (CTL) learning model based on creative thinking in this school.

Data analysis is the process of systematically searching and arranging data obtained from interviews, field notes, and documentation, by organizing data into categories, describing them into units, synthesizing, arranging into patterns, choosing which ones are important and which will be. learned, and make conclusions so that they are easily understood by oneself and others [31]. The data analysis technique used in this study is an interactive analysis technique (model), namely qualitative data analysis which consists of three activities, namely (1) data reduction, (2) data presentation, and (3) drawing conclusions and verification (21). The continuous interactive process of these three components requires the discipline of the researcher so that he does not experience difficulties in carrying out the final analysis process to formulate research conclusions when the data collection process has ended.

\section{RESULT AND DISCUSSION}

\subsection{Result}

The learning model of contextual teaching and learning is a learning model that requires the involvement of students in the learning process by connecting the life around them in real terms. Research on the application of contextual teaching and learning (CTL) learning model based on creative thinking describes how to apply this model to students. In the implementation of contextual teaching and learning (CTL) learning model based on creative thinking in class IV SDIT An Nisa 'Kedawung, there are three kinds of learning steps applied in elementary schools, namely:

\subsubsection{Planning}

At the planning stage, the teacher plans learning which is used as the basis for the learning process. Learning planning is following the curriculum currently implemented in elementary schools. The curriculum used at this time is the 2013 curriculum. The 2013 curriculum is an integrated curriculum, which means a curriculum model that can integrate skills, themes, concepts, and topics both in single disciplines, across several disciplines, and within and across learners [17]. The 2013 curriculum is a curriculum that integrates several subjects into one theme in learning in elementary schools.

In the lesson planning, the teacher prepares learning tools that can be used to help the smoothness and success of learning. This effort is a step to achieve the basic competencies that have been determined in the 2013 curriculum. In the 2013 curriculum, aspects of the 2013 curriculum assessment include spiritual aspects, attitude aspects, knowledge aspects, and skills aspects. While the planning includes: annual program, a semester program, a syllabus, and a lesson plan (RPP).

The planning stage in this research is to apply contextual teaching and learning based on creative thinking to be applied in learning which aims to teach students to learn creatively and fun so that students will get meaningful experiences. Contextual learning has several distinctive characteristics, which distinguish it from other learning approaches. The characteristics of the contextual approach are (a) cooperation, (b) mutual support, (c) fun, (d) not boring, (e) learning with passion, (f) integrated learning, (g) active students, (h) sharing with friends, (i) using various sources, (j) critical students and creative teachers, $(\mathrm{k})$ classroom walls and hallways full of student work, and (l) report to parents are not report cards, but student work.

\subsubsection{Implementation}

The implementation stage of learning includes initial activities, core activities, and final activities. In the initial activity, the teacher performs apperception to direct students into learning material about caring for living thingsDoes master ask questions about whether we need animals and plants around us? then if we need efforts what is done to protect it?. By asking these questions will direct the thinking of students to reason about what answers are appropriate based on their observations in the environment.

In the core activities, the teacher makes observations according to the division of group assignments. Where the task of this group of teachers gives assignments to students based on observations that have been carried out by students on learning materials that have been implemented in the field, by the procedures from the teacher. The purpose of this observation, students can observe each learning process and can try to apply the knowledge obtained in the surrounding environment. After carrying out observations, students note what important things are obtained based on the observations that have been carried out, including knowing how to keep the environment clean, how to keep plants from dying, and so on. In activities in the classroom, the teacher discusses how he has learned with his group friends. If the students have finished carrying out the discussion then the students report to the teacher about the results of the discussions that have been carried out.

In the final activity, to determine the level of understanding of students, the teacher provides evaluation questions to work on. This evaluation question is used as a measuring tool to determine students' understanding of the learning objectives to be achieved. The evaluation question is in the form of a description, where students make essays based on what they see and 
their experiences in making observations on material caring for living things.

\subsubsection{Closing}

In the closing activity, the teacher and students communicate the learning and conclude the results of the observations that have been carried out following the indicators that must be achieved by students. In the closing activity, the individual assignments that are collected are essays based on the observations that have been made by students by writing down what they have seen based on direct observation. The activities carried out by the teacher in the closing activities were concluding the learning material and closing the learning activities with prayers and closing greetings.

\subsection{Discussion}

In the implementation of the contextual teaching and learning model based on creative thinking in elementary schools, it is known from observations and observations during the implementation of the learning that has been implemented. At the implementation stage of learning, students carry out activities by observing the environment around them. Students carry out learning with teacher guidance. The teacher guides students during the discussion in knowing living things, including plants and animals. At the learning implementation stage, there are obstacles in each learning implementation. These obstacles include carrying out discussions, of course, there are active and less active students. This has an impact on the lack of information obtained by students so that the material presented has not been well received. Based on these obstacles, it is necessary to find solutions to overcome these problems, one of which is by directing students to think creatively about the learning material being studied.

\section{CONCLUSIONS}

Based on the main findings and discussion of research results on the application of contextual teaching and learning (CTL) learning model based on creative thinking, it can be concluded as follows:

At the planning stage, the teacher implements learning according to the learning implementation plan (RPP) which is adjusted to the basic competencies, indicators, and learning objectives that students must achieve based on the 2013 curriculum.

At the learning stage, contextual teaching and learning based on creative thinking include planning, material selection, and learning models. The implementation stage of learning includes initial activities, core activities, and final activities. In the initial activity, the teacher performs apperception to direct students into learning materials about caring for living things. In the core activities, the teacher makes observations according to the division of group assignments. Where the task of this group of teachers gives assignments to students based on observations that have been carried out on learning materials that have been implemented in the field, according to the procedures from the teacher. In the final activity to find out the level of understanding of students, the teacher provides evaluation questions to work on. This evaluation question is used as a measuring tool to determine students' understanding of the learning objectives to be achieved.

In the closing activity, students and teachers conclude the results of observations that have been carried out by the indicators that must be achieved by students. Individual assignments that are collected are in the form of stories based on observations that have been carried out. The teacher closes the learning activity by singing one of the regional songs

\section{REFERENCES}

[1] Alkhawalda, M. and I. Abdulaziz. Effectiveness of peer-teaching based program in improving creative thinking skills and learning motivation among gifted students. Education Journal, Vol. 2, No. 151. 2012

[2] Antonietti, A. 2000. Enhancing creative analogies in primary school children. North American. Journal of Psychology, Vol.2

[3] Anwar, N. M., Aness, M., \& Khizar, A. 2012 Relationship of Creative Thinking with Academic Achievements of Secondary School Students (2012), International Interdisciplinary Journal of Education, Vol. 1, No. 3

[4] Arikunto. 2016. Prosedur Penelitian Suatu Pendekatan Praktik. Jakarta: Rineka Cipta

[5] Aslan, N., \& Cansever, B. A. 2009. The primary school teachers ${ }^{\text {ee }}$ attitudes for creativity in education. TUBAV Science Journal, Vol. 2, No.3

[6] Bakar, Rudd. 2001. Relationships between Critical and Creative Thinking. Journal of Southern Agricultural Education Research, Vol. 51, No.1

[7] Batlolona, J.R., Diantoro, M., Wartono, \& Latifah, E. (2019). Creative thinking skills students in physics on solid material elasticity. Journal of Turkish Science Education, 16(1), 48-61. DOI: 10.12973/tused.10265a

[8] Borodina, Sibgatullina, \& Gizatullina. 2019. Developing Creative Thinking in Future Teachers as a Topical Issue of Higher Education. Journal of Social Studies Education Research, Vol. 10. Kazan Federal University, Rusia. 226-245 
[9] Cenberci, S. 2018. The Investigation of the Creative Thinking Tendency of Prospective Mathematics Teachers in Terms of Different Variables. Journal of Education and Training Studies, Vol. 6, Necmettin Erbakan University, Turkey. doi:10.11114/jets.v6i9.3434

[10] Driver R., Asoko, H., Leach, J., Mortimer, E., \& Scott, P. 1994. Constructing scientific knowledge in the classroom. Educational Researcher, Vol. 23, No. 7

[11] Fadilah, Dewi, Ridho, Majid, \& Prastiwi. 2016. The effect of application of contextual teaching and learning (CTL) model-based on lesson study with mind mapping media to assess student learning outcomes on chemistry on colloid systems. International Journal of Science and Applied Science: Conference Series, Vol. 1. Yogyakarta State University, Yogyakarta. DOI: 10.20961/ijsascs.v1i2.5128

[12] Garaigordobil, Berrueco. 2011. Effects of a Play Program on Creative Thinking of Preschool Children. The Spanish Journal of Psychology, Vol. 14. Universidad del País Vasco, Spain. 608-618

[13] Glynn. 2004. Contextual Teaching and Learning of Science in Elementary Schools. Journal of Elementary Science Education. Vol. 16. Department of Science Education, Western Illinois University. pp. 51-63

[14] Ibrahim, A. (2006). The impact of multiple intelligences program of science teachers on developing creative teaching and problem-solving skills among students. Journal of Scientific Education-Al-Azhar University, Gaza, 9(4), 27-89

[15] Ilhan, Nail et al. 2016. The Effect of Context-based Chemical Equilibrium on Grade 11 Students' Learning, Motivation and Contructivist Learning Environment. International Journal of Environment \& Science Education, Vol. 11, No. 9

[16] K Yin, Robert. 2013. Studi Kasus Desain dan Metode. Jakarta: PT. Raja Grafindo Persada

[17] Loeloek, Sofan. 2013. Panduan Memahami Kurikulum 2013. Jakarta: PT Prestasi Pustakarya

[18] Long, Balakrishnan, Ying Yan. 2020. Effectivness of Creative Thinking Module on Figural Creativity of Engineering Undergraduate in Malaysia. International Journal of Higher Education, Vol. 9. Universiti Pendidikan Sultan Idris, Malaysia. doi:10.5430/ijhe.v9n4p233

[19] Mardianto, \& Wijaya, E. L. (2016). The Effect of Contextual Teaching and Learning (CTL) and Conventional Method on Mathematics Thinking Ability of Islamic Senior High School Student 1 in Medan. Journal of Arts, Science \& Commerce, 7(4), 100-107

[20] Marsh, Patricia A. 2007. What is Known about Student Learning Outcomes and How does it relate to the Scholarship of Teaching and Learning. International
Journal for the Scholarship of Teaching and Learning, Vol. 1, No 2

[21] Miles,M.B, Huberman,A.M, dan Saldana,J. 2014. Qualitative Data Analysis, A Methods Sourcebook, Edition 3. USA: Sage Publications. Terjemahan Tjetjep Rohindi Rohidi, UI-Press

[22] Mulyana. 2010. Metodologi Penelitian Kualitatif. Bandung: PT. Remaja Rosdakarya

[23] Nawas. 2018. Contextual Teaching and Learning (CTL) Approach through REACT Strategies on Improving the Students' Critical Thinking in Writing. International Journal of Management and Applied Science, Vol. 4. University of Adelaid, Adelaide South Australia. http://iraj.in

[24] Ndiung, S., Dantes, N., Ardana, I. M., \& Marhaeni, A. A. I. N. Treffinger Creative Learning Model with RME Principles on Creative Thinking Skill by Considering Numerical Ability. International Journal of Instruction, 12(3), 2019, pp.731-744. DOI: https://doi.org/10.29333/iji.2019.12344a

[25] Pangemanan. 2019. Application of Contextual Teaching and Learning Approach on Statistics Material Against Student Results. International Education Studies, Vol. 13. Manado State University, North Sulawesi, Indonesia. doi:10.5539/ies.v13n4p1

[26] Puspitasari, In'am, \& Syaifuddin. 2019. Analysis of Students' Creative Thinking in Solving Arithmetic Problems. International Electronic Journal Of Mathematics Education. Vol. 14. University of Muhammadiyah Indonesia.https://doi.org/10.12973/iejme/3962

[27] Redifer, Bae, Lane. 2019. Implicit Theories, Working Memory, and Cognitive Load: Impacts on Creative Thinking. Original Research, Vol. 1. Western Kentucky University. DOI:10.1177/2158244019835919

[28] Rowais. 2019. Effectiveness of Marzano's Dimensions of Learning Model in the Development of Creative Thinking Skills among Saudi Foundation Year Students. World Journal of Education, Vol. 9. Al Imam Mohammad Ibn Saud Islamic University, Riyadh, Saudi Arabia. DOI:10.5430/wje.v9n4p49

[29] Sanel, Birsen. 2019. Development of Creative Thinking Skills of Students Through Journal Writing. International Journal of Progressive Education, Vol. 15. Gaziantep University, DOI: 10.29329/ijpe.2019.212.15

[30] Sugiyanto, Masykuri, \& Muzzazinah. Analysis of senior high school students' creative thinking skills profile in Klaten regency. International Conference on Science Education. 2018. DOI:10.1088/1742$6596 / 1006 / 1 / 012038$ 